\title{
TEMPERATURE AND IONIC STRENGTH INFLUENCE ON U(VI/V) AND U(IV/III) REDOX POTENTIALS IN AQUEOUS ACIDIC AND CARBONATE SOLUTIONS
}

\author{
H. CAPDEVILA, P. VITORGE \\ Laboratoire de Chimie CEA IRDI/DERDCA/DRDD/SESD/SCPCS \\ 92265 Fontenay aux Roses, Cedex (France)
}

(Received February 2, 1990)

\begin{abstract}
Redox potentials: $\mathrm{E}\left(\mathrm{UO}_{2}^{2+} / \mathrm{UO}_{2}^{+}\right)=60 \pm 4 \mathrm{mV} / \mathrm{NHE}, \mathrm{E}\left(\mathrm{U}^{4+} / \mathrm{U}^{3+}\right)=-630 \pm 4 \mathrm{mV} / \mathrm{NHE}$ measured at $25^{\circ} \mathrm{C}$ in acidic medium $\left(\mathrm{HClO}_{4} 1 \mathrm{M}\right)$ using cyclic voltametry are in accordance with the published data. From $5{ }^{\circ} \mathrm{C}$ to $55{ }^{\circ} \mathrm{C}$ the variations of the potentials of these systems (measured against $\mathrm{Ag} / \mathrm{AgCl}$ electrode) are linear. The entropies are then constant: $\left[\Delta \mathrm{S}\left(\mathrm{UO}_{2}^{2+}\right]\right.$ $\left.\left.\mathrm{UO}_{2}^{+}\right)-\Delta \mathrm{S}(\mathrm{Ag} / \mathrm{AgCl})\right] / \mathrm{F}=0 \pm 0.3 \mathrm{mV} /{ }^{\circ} \mathrm{C},\left[\Delta \mathrm{S}\left(\mathrm{U}^{4+} / \mathrm{U}^{3+}\right)-\Delta \mathrm{S}(\mathrm{Ag} / \mathrm{AgCl})\right] / \mathrm{F}=1.5 \pm 0.3$ $\mathrm{mV} /{ }^{\circ} \mathrm{C}$. From $5{ }^{\circ} \mathrm{C}$ to $55^{\circ} \mathrm{C}$, in carbonate medium $\left(\mathrm{Na}_{2} \mathrm{CO}_{3}=0.2 \mathrm{M}\right)$, the Specific Ionic In-

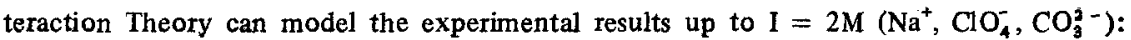
$\mathrm{E}\left(\mathrm{UO}_{2}\left(\mathrm{CO}_{3}\right)_{3}^{4-} / \mathrm{UO}_{2}\left(\mathrm{CO}_{3}\right)_{3}^{5-}\right)=-778 \pm 5 \mathrm{mv} / \mathrm{NHE}\left(\mathrm{I}=0, \mathrm{~T}=25^{\circ} \mathrm{C}, \Delta \epsilon\left(25^{\circ} \mathrm{C}\right)=\right.$ $=e\left(\mathrm{UO}_{2}\left(\mathrm{CO}_{3}\right)_{3}^{4-}, \mathrm{Na}^{+}\right)-e\left(\mathrm{UO}_{2}\left(\mathrm{CO}_{3}\right)_{3}^{5-}, \quad \mathrm{Na}^{+}\right)=0.92 \mathrm{~kg} / \mathrm{mole}, \Delta \mathrm{S}\left(\mathrm{UO}_{8}\left(\mathrm{CO}_{3}\right)_{3}^{4-}\right.$ $/ \mathrm{UO}_{2}\left(\mathrm{CO}_{3}\right)_{3}^{5-}=-1.8 \pm 0.5 \mathrm{mV} /{ }^{\circ} \mathrm{C}(\mathrm{I}=0), \Delta \epsilon=\epsilon\left(\mathrm{Cl}^{-}, \mathrm{Na}\right)=(1.14-0.007 \mathrm{~T}) \mathrm{kg} / \mathrm{mole}$. The $U(\mathrm{VI} / \mathrm{V})$ potential shift, between carbonate and acidic media, is used to calculate (at $\left.\mathrm{I}=0,25^{\circ} \mathrm{C}\right)$ :
\end{abstract}

$$
\log \frac{\beta_{3} \mathrm{U}(\mathrm{V})}{\beta_{3} \mathrm{U}(\mathrm{VI})}=-14.7 \pm 0.5
$$

and then

$$
\log \beta_{3} U(V)=6.6 \pm 0.3
$$

\section{Introduction}

In order to assess the safety of the storage of nuclear waste, it is important to know the behaviour of radioelements in the environment, and especially their redox potentials. Experimental conditions are very often different from natural ones: the ionic strength of aqueous solutions used for the electrochemical measurements is much higher than in deep groundwaters, where the temperature is also higher than $25^{\circ} \mathrm{C}$.

In acidic medium, the Specific Interaction Theory (S. I. T.) can model the activity coefficients $^{1-2}$ of cations with reasonable precision (except, perhaps, for the highly 
charged tetravalent cations). ${ }^{2}$ In carbonate medium, there is very little experimental evidence $^{3}$ that the S. I. T. can be used to determine the standard potential (at 0 ionic strength) of anions.

The objective of the present work is to measure the redox potential of the couple $\mathrm{UO}_{2}\left(\mathrm{CO}_{3}\right)_{3}^{4-} / \mathrm{UO}_{2}\left(\mathrm{CO}_{3}\right)_{3}^{5-}$ to test $\mathrm{S}$. I. T. theory with the highly charged anionic limiting complexes of hexavalent and pentavalent uranium, that exist in concentrated carbonate solutions. ${ }^{4}, 5$ The poor precision of published results on the entropy of actinide ions induces uncertainties on the redox potentials at high temperature; ${ }_{;}^{2}$ so we decided to study the variation of the redox potentials of the couples $\mathrm{UO}_{2}^{2+} / \mathrm{UO}_{2}^{+}$, $\mathrm{U}^{4+} / \mathrm{U}^{3+}$ and $\mathrm{UO}_{2}\left(\mathrm{CO}_{3}\right)_{3}^{4-} / \mathrm{UO}_{2}\left(\mathrm{CO}_{3}\right)_{3}^{5-}$ versus temperature.

\section{Notations}

$\log$

$\ln$

$\mathbf{z}_{\mathbf{i}}$

$\Delta \mathrm{z}^{2}$

[i]

$\mathrm{m}_{\mathbf{i}}$

$\mathrm{m}_{\mathrm{R}}$

$\mathrm{m}_{\mathrm{s}}$

$\mathrm{T}$

$\mathrm{I}_{\mathrm{S}}$

$I_{R}$

$\mathrm{D}(\mathrm{T}, \mathrm{I})$

- decimal logarithm,

- natural logarithm,

- charge of ion $\mathbf{i}$,

$=z^{2} O x^{-} z^{2}$ Red,

- molarity of ion $\mathrm{i}(\mathrm{mol} / \mathrm{l}=\mathrm{M})$,

- molality of ion $\mathrm{i}=$ concentration $(\mathrm{mol} / \mathrm{kg})$,

- in carbonate medium, $m_{R}=m_{N a+}$ of the reference compartment, in acidic medium, $\mathrm{m}_{\mathrm{R}}=\mathrm{m}_{\mathrm{ClO}_{4}}{ }^{-}$,

- in carbonate medium, $\mathrm{m}_{\mathrm{R}}=\mathrm{m}_{\mathrm{Na}}$ of the working solution,

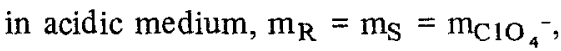

- temperature solution,

- ionic strength of the working solution $(\mathrm{mol} / \mathrm{kg})$,

- ionic strength of the reference solution $(\mathrm{mol} / \mathrm{kg}$ ),

A

- Debye-Hückel term ${ }^{6} \mathrm{D}=\mathrm{a} \frac{\sqrt{\mathrm{I}}}{1+\mathrm{ba}_{\mathrm{j}}^{0} \sqrt{I}}$

$=\frac{R T \ln (10)}{F}=59.16 \mathrm{mV}\left(\right.$ at $\left.25^{\circ} \mathrm{C}\right)$,

$\epsilon(\mathrm{i}, \mathrm{j})$

$\Delta \epsilon(\mathrm{T})$

$\epsilon_{\mathrm{C} 1-}(\mathrm{T})$

$\Delta \epsilon^{\prime}(\mathrm{T})$

- specific interaction coefficient between ions $i$ and $j$ of opposite charge $\left(i=\right.$ Ox or Red), in acidic medium $\mathrm{j}=\mathrm{ClO}_{4}^{-}$, in carbonate medium $\mathrm{j}=\mathrm{Na}^{+}$,

$=\epsilon(\mathrm{Ox}, \mathrm{j})-\epsilon(\operatorname{Red}, \mathrm{j})$,

$=\epsilon\left(\mathrm{Na}^{+}, \mathrm{Cl}^{-}\right)=0.03$ at $25^{\circ} \mathrm{C}^{6}$,

$=\Delta \epsilon(\mathrm{T})+\epsilon_{\mathrm{Cl}^{-}}(\mathrm{T})$, 


$$
\begin{array}{ll}
\mathrm{E}_{1 / 2}(\mathrm{~T}, \mathrm{I}) & - \text { half-wave potential measured by cyclic voltametry against } \\
& \mathrm{Ag} / \mathrm{AgCl} \text { reference, } \\
\text { index } \mathrm{O} / \mathrm{R} & - \text { for a potential measured against } \mathrm{NHE}, \\
\mathrm{E}_{\mathrm{O} / \mathrm{R}}\left(\mathrm{T}, \mathrm{I}_{\mathrm{S}}\right) & - \text { potential of } \mathrm{Ox} / \mathrm{Red} \text { when }[\mathrm{Ox}]=[\mathrm{Red}] \text { formal potential, } \\
\mathrm{E}_{\mathrm{O} / \mathrm{R}}(25,0) & - \text { standard potential of } \mathrm{Ox} / \mathrm{Red}, \\
\mathrm{E}_{\mathrm{Ref}}\left(\mathrm{T}, \mathrm{I}_{\mathrm{R}}\right) & \left.-\mathrm{Ag} / \mathrm{AgCl} \text { potential at } \mathrm{I}_{\mathrm{R}}, \mathrm{T} \text { and }[\mathrm{Cl}]^{-}\right]=0.02 \mathrm{M}, \\
\mathrm{E}_{\mathrm{Ag} / \mathrm{AgCl}}(\mathrm{T}, 0) & -\mathrm{Ag} / \mathrm{AgCl} \text { potential at } \mathrm{I}=0, \mathrm{~T} \text { and } \mathrm{m}_{\mathrm{Cl}^{-}}=1, \\
\Delta \mathrm{S}_{\mathrm{a}}^{\mathrm{b}}(\mathrm{T}, \mathrm{I}) & =\mathrm{F}\left(\frac{\partial \mathrm{E}_{\mathrm{a}}^{\mathrm{b}}(\mathrm{T}, \mathrm{I})}{\partial \mathrm{T}}\right)_{\mathrm{p}, \mathrm{ni}} \\
\beta_{3}[\mathrm{M}(\mathrm{VI}) \text { or } \mathrm{M}(\mathrm{V})]= & \frac{\left[\mathrm{MO}_{2}\left(\mathrm{CO}_{3}\right)_{3}^{\mathrm{i}-6}\right]}{\left[\mathrm{MO}_{2}^{\mathrm{i}+}\right]\left[\mathrm{CO}_{3}^{2}-\right]^{3}} \text { where } \mathrm{MO}_{2}^{\text {i+ }} \text { is an actinide of redox number } \\
& \mathrm{VI} \text { or } \mathrm{V} .
\end{array}
$$

\section{Experimental}

\section{Apparatus}

To measure redox potentials of uranium systems we have chosen the cyclic voltametry technique. The reasons of this choice and the circuit description have been already published. ${ }^{1}{ }^{2}$ We used a classical 3 -electrode circuit. The platinum counter electrode was put directly in the working solution. In acidic medium, to stabilize the $\mathrm{Ag} / \mathrm{AgCl}$ reference electrode that was directly put in the cell solution, $0.02 \mathrm{M} \mathrm{Cl}^{-}$ was added in the supporting electrolyte $\mathrm{NaClO}_{4}$. In carbonate medium, the $\mathrm{Ag} / \mathrm{AgCl}$ reference electrode was put in a microcapillary low leakage junction, filled with $\left(\mathrm{NaClO}_{4} \mathrm{I}_{\mathrm{R}} \mathrm{M} ; \mathrm{NaCl} 0.02 \mathrm{M}\right)$ solution. This separated compartment was used in order to avoid the precipitation of $\mathrm{AgCO}_{3}$. The working electrode was a hanging $\mathrm{Hg}$ drop electrode.

\section{Reagents}

The uranium stock solution was prepared from uranyl nitrate $\left[\mathrm{UO}_{2}\left(\mathrm{NO}_{3}\right)_{2}, 6 \mathrm{H}_{2} \mathrm{O}\right]$. It was dissolved in $\mathrm{HNO}_{3} 1 \mathrm{~N}$ Prolabo acid. Then, adding $\mathrm{Na}_{2} \mathrm{CO}_{3}$ Prolabo to the solution, we precipitated the yellow solid $\mathrm{UO}_{2} \mathrm{CO}_{3}$. This precipitate was redissolved in $1 \mathrm{M} \mathrm{HClO}_{4}$, prepared from $\mathrm{HClO}_{4}$ Prolabo $70 \%$. The stock solution was analyzed spectrophotometrically: the U(VI) concentration was $0.21 \mathrm{~mol} / 1$. The working solutions were millimolar uranium ones. In carbonate (or acidic) medium the stock solu- 
tion was diluted in solutions of different ionic strengths $\left(0.2 \mathrm{M} \mathrm{Na} \mathrm{NO}_{3}, x M \mathrm{NaClO}_{4}\right)$ (or $\mathrm{HClO}_{4} 1 \mathrm{M}$ ) where $\mathrm{x}=2.6,1.4,0.6$, or $0 \mathrm{M}$.

\section{Measurements}

The temperature was regulated by a Haake F3 thermostat and controlled with a thermometer immersed in the working solution. Before recording the voltamperogram, the oxygen was eliminated from the solution by bubbling argon for 10 minutes. For each system and each temperature (from $5{ }^{\circ} \mathrm{C}$ to $55^{\circ} \mathrm{C}$ ) a voltamperogram was recorded. Between two different measurements we waited at least 15 minutes to stabilize the cell solution temperature.

In acidic medium: Both systems $\mathrm{UO}_{2}^{2+} / \mathrm{UO}_{2}^{+}$and $\mathrm{U}^{4+} / \mathrm{U}^{3+}$ were studied. For $\mathrm{UO}_{2}^{2+} / \mathrm{UO}_{2}^{+}$the voltamperogram is recorded from $\mathrm{E}=-100 \mathrm{mV}$ to $-450 \mathrm{mV}$ against the reference $\mathrm{Ag} / \mathrm{AgCl}$ electrode, whose potential in this medium $\left(\mathrm{HClO}_{4} \mathrm{1M}, \mathrm{NaCl}\right.$ $0.02 \mathrm{M}$ ) is $327.8 \mathrm{mV}$ at $25^{\circ} \mathrm{C}$ (it was calculated using the S. I. T.) To study the system $\mathrm{U}^{4+} / \mathrm{U}^{3+}$ we started with a $\mathrm{UO}_{2}^{2+}$ solution. To obtain $\mathrm{U}^{3+}$ species in the diffusion layer of the hanging $\mathrm{Hg}$ drop electrode, the solution was reduced at $-1100 \mathrm{mV}$ for 1 minute; then the $\mathrm{U}^{4+} / \mathrm{U}^{3+}$ voltamperogram was recorded from $-1100 \mathrm{mV}$ to $-750 \mathrm{mV}$.

In carbonate medium: The $\mathrm{UO}_{2}\left(\mathrm{CO}_{3}\right)_{3}^{4-} / \mathrm{UO}_{2}\left(\mathrm{CO}_{3}\right)_{3}^{5-}$ voltamperogram was recorded from $-300 \mathrm{mV}$ to $-1500 \mathrm{mV}$. We studied the ionic strength and temperature influences on the redox potential.

\section{Method and treatment of data}

Ionic strength influence

The half-wave potential, $E_{1 / 2}(T, I)$, measured using cyclic voltametry, is a good approximation of $\mathrm{E}_{\mathrm{O} / \mathrm{R}}(\mathrm{T}, \mathrm{I})$, the working half-cell potential when $[\mathrm{Ox}]=[\operatorname{Red}]:^{2}$

$$
E_{1 / 2}(T, I)=E_{O / R}\left(T, I_{S}\right)-E_{R e f}\left(T, I_{R}\right)
$$

The potentials of uranium systems are measured at varying ionic strengths. To model the results and extrapolate to $I=0$ we used the Specific Interaction Theory (S. I. T. $)^{1}{ }^{2}$ and NERNST law for both half cells:

$$
\begin{aligned}
& E_{O / R}\left(T, I_{S}\right)=E_{O / R}(T, O)+A(T)\left[-\Delta z^{2} D\left(T, I_{s}\right)+\Delta \epsilon(T) m_{s}\right] \\
& E_{R e f}\left(T, I_{R}\right)=E_{A g / A g C l}(T, O)-A(T)\left[-D\left(T, I_{R}\right)+\epsilon_{C I^{-}}(T) m_{R}+\log \left(m_{C 1^{-}}\right)\right]
\end{aligned}
$$


Inserting Eqs (2) and (3) into Eq. (1), one obtains:

$$
\mathrm{E}_{1 / 2}(\mathrm{~T}, \mathrm{I})=\mathrm{E}_{1 / 2}(\mathrm{~T}, \mathrm{O})+\mathrm{A}(\mathrm{T})\left[-\Delta \mathrm{z}^{2} \mathrm{D}\left(\mathrm{T}, \mathrm{I}_{\mathrm{S}}\right)-\mathrm{D}\left(\mathrm{T}, \mathrm{I}_{\mathrm{R}}\right)+\Delta \epsilon^{\prime}(\mathrm{T}) \mathrm{m}_{\mathrm{S}}+\epsilon(\mathrm{T})\left(\mathrm{m}_{\mathrm{R}}-\mathrm{m}_{\mathrm{S}}\right)\right]
$$

where

$$
E_{1 / 2}(T, O)=E_{O / R}(T, O)-E_{A g / A g C l}(T, O)+A \log \left(m_{\mathrm{Cl}^{-}}\right)
$$

In our experimental conditions $\Delta \mathrm{m}=\left(\mathrm{m}_{\mathrm{R}}-\mathrm{m}_{\mathrm{S}}\right) \ll \mathrm{m}_{\mathrm{S}}$.

\section{In carbonate medium}

$$
\begin{aligned}
& \mathrm{I}_{\mathrm{R}}=\left[\mathrm{m}_{\mathrm{R}} \mathrm{ClO}_{4}^{-}+\mathrm{m}_{\mathrm{R}} \mathrm{Na}^{+}\right] / 2 \\
& \mathrm{I}_{\mathrm{S}}=\left[\mathrm{m}_{\mathrm{S}} \mathrm{ClO}_{4}^{-}+\mathrm{m}_{\mathrm{S}} \mathrm{Na}^{+}+4 \mathrm{~m}_{\mathrm{S}} \mathrm{CO}_{3}^{2-}\right] / 2
\end{aligned}
$$

In S. I. T. approximation, Eq. (4) is used for linear regression (at $\mathrm{T}=25^{\circ} \mathrm{C}$ ): the plot of

$$
\left(\frac{\mathrm{E}_{1 / 2}\left(25^{\circ} \mathrm{C}, \mathrm{I}\right)}{\mathrm{A}\left(25^{\circ} \mathrm{C}\right)}+\Delta \mathrm{z}^{2} \mathrm{D}\left(25^{\circ} \mathrm{C}, \mathrm{I}_{\mathrm{s}}\right)+\mathrm{D}\left(25^{\circ} \mathrm{C}, \mathrm{I}_{\mathrm{R}}\right)-\epsilon\left(25^{\circ} \mathrm{C} \Delta \mathrm{m}\right)\right.
$$

versus $m_{S}$ is a straight line, whose slope is $\Delta \epsilon^{\prime}\left(25^{\circ} \mathrm{C}\right)$ and the intercept $m_{S}=0$ is $\frac{\mathrm{E}_{1 / 2}\left(25^{\circ} \mathrm{C}, 0\right)}{\mathrm{A}\left(25^{\circ} \mathrm{C}\right)}$.

In Eq. (5), $\mathrm{E}_{1 / 2}\left(25^{\circ} \mathrm{C}, 0\right)$ is calculated from experimental results, $\mathrm{m}_{\mathrm{Cl}^{-}}$is an experimental value, and $\mathrm{E}_{\mathrm{Ag} / \mathrm{AgCl}}\left(25^{\circ} \mathrm{C}, 0\right)$ is published, ${ }^{7}$ so we can deduce $\mathrm{E}_{\mathrm{O} / \mathrm{R}}\left(25^{\circ} \mathrm{C}, 0\right)$ (it is the standard potential).

\section{Temperature influence}

To compare our results with published entropy values, we used the GIBBS-HELMOTZ relation

$$
\left(\frac{\partial \mathrm{G}}{\partial \mathrm{T}}\right)_{\mathrm{p}, \mathrm{ni}}=-\mathrm{S}
$$


and

$$
\Delta \mathrm{G}=-\mathrm{nFE}
$$

Substitution of (6) into (7) leads to

$$
\mathrm{F}\left(\frac{\partial \mathrm{E}}{\partial \mathrm{T}}\right)_{\mathrm{p}, \mathrm{ni}}=\Delta \mathrm{S}
$$

where $\mathrm{E}, \Delta \mathrm{S}$ and $\Delta \mathrm{G}$ refer to the same equilibrium:

$$
\mathrm{Ox}+\mathrm{ne}^{-} \rightleftharpoons \operatorname{Red}
$$

All the potentials were measured against a $\mathrm{Ag} / \mathrm{AgCl}$ reference electrode. Since both $\mathrm{E}_{\mathrm{O} / \mathrm{R}}$ and $\mathrm{E}_{\mathrm{Ag} / \mathrm{AgCl}}$ depend on temperature, reporting Eq. (8) into Eq. (1), one obtained the following relation:

$$
\Delta S_{1 / 2}(T, I)=\Delta S_{O / R}\left(T, I_{s}\right)-\Delta S_{R e f}\left(T, I_{R}\right)
$$

In carbonate medium: to extrapolate to $\mathrm{I}=0$ using the $\mathrm{S}$. I. T., we had to make an approximation. $\epsilon\left(\mathrm{Na}^{+}, \mathrm{Cl}^{-}\right)$is only known at $25{ }^{\circ} \mathrm{C}$. So, at $\mathrm{T} \neq 25^{\circ} \mathrm{C}$ we supposed that:

$$
\epsilon_{\mathrm{Cl}^{-}}(\mathrm{T})=\epsilon_{\mathrm{Cl}^{-}}\left(25^{\circ} \mathrm{C}\right)+\frac{\partial \epsilon}{\partial \mathrm{T}}\left(25^{\circ} \mathrm{C}\right)(\mathrm{T}-25)
$$

Reporting Eq. (11) into Eq. (4), we then neglected the second order term $\frac{\partial \epsilon}{\partial \mathrm{T}}\left(25{ }^{\circ} \mathrm{C}\right)(\mathrm{T}-25$

- $\Delta \mathrm{m}$. Using the above linear regression, we determined for each temperature $\mathrm{E}_{1 / 2}(\mathrm{~T}, \mathrm{O})$ and $\Delta \epsilon^{\prime}(\mathrm{T}) . \mathrm{E}_{\mathrm{Ag} / \mathrm{AgCl}}(\mathrm{T}, \mathrm{O})$ is published for any temperature from 5 to $55^{\circ} \mathrm{C}$, so we deduced $\mathrm{E}_{\mathrm{O} / \mathrm{R}}(\mathrm{T}, \mathrm{O})$ values. Since

$$
\frac{\Delta \mathrm{S}_{\mathrm{O} / \mathrm{R}}(\mathrm{T}, \mathrm{O})}{\mathrm{F}}=\frac{\partial \mathrm{E}_{\mathrm{O} / \mathrm{R}}(\mathrm{T} . \mathrm{O})}{\partial \mathrm{T}}
$$

the variation of $E_{O / R}(T, O)$ versus $T$ allowed to determine $\Delta S_{O / R}(T, O)$. 


\section{Results}

\section{In acidic medium}

The $\mathrm{UO}_{2}^{2+} / \mathrm{UO}_{2}^{+}$and $\mathrm{U}^{4+} / \mathrm{U}^{3+}$ couples have been studied at varying potential scanning speeds. From 5 to $800 \mathrm{mV} / \mathrm{s}$, neither the voltamperogram shape nor the value of the half-wave pr:-...jal changed. So, we considered that both systems are reversible on hanging $\mathrm{Hg}$ drop electrode, and that half-wave potential are good approximation of formal potential. ${ }^{1,2}$

We used a scanning speed of $60 \mathrm{mV} / \mathrm{s}$ (or $200 \mathrm{mV} / \mathrm{s}$ ) for $\mathrm{UO}_{2}^{2+} / \mathrm{UO}_{2}^{+}$(or $\mathrm{U}^{4+} / \mathrm{U}^{3+}$ ) system. The formal potential that we measured in $\mathrm{HClO}_{4} 1 \mathrm{M}$ using cyclic voltametry is in agreement with the one obtained by polarography. ${ }^{1}{ }^{2}$ The temperature has no influence on $\mathrm{UO}_{2}^{2+} / \mathrm{UO}_{2}^{+}$system. For $\mathrm{U}^{4+} / \mathrm{U}^{3+}$, the plot of $\mathrm{E}(\mathrm{T}, 1)$ versus $\mathrm{T}$ is a straight line whose slope is $\Delta \mathrm{S}(\mathrm{T}, 1) / \mathrm{F}$ (cf. Method section). All the results in acidic medium are compiled in Table 1.

\section{In carbonate medium}

For the system $\mathrm{UO}_{2}\left(\mathrm{CO}_{3}\right)_{3}^{4-} / \mathrm{UO}_{2}\left(\mathrm{CO}_{3}\right)_{3}^{5-}$, the scanning speed changes the voltamperogram shape, but the half-wave potential remains constant. The system is not reversible on this working electrode but it is possible to measure formal potential of this couple by this technique. For all measurements we used a scanning speed of $300 \mathrm{mV} / \mathrm{s}$. For each temperature, the S. I. T. (cf. Method section) was used to extrapolate to $\mathrm{I}=0$. So, we determined the potentials $\mathrm{E}_{1 / 2}(\mathrm{~T}, 0), \Delta \epsilon^{\prime}(\mathrm{T})$ and then $\mathrm{E}_{\mathrm{O} / \mathrm{R}}(\mathrm{T}, 0)$. In these conditions, the $\mathrm{S}$. I. T. fit correctly the data up to only $\mathrm{I}=2 \mathrm{M}$, and this is the same for all temperatures. For each ionic strength we plotted $E_{1 / 2}(T, I)$ versus $T$. We obtained straight lines, as in acidic medium, whose slopes are $\Delta S_{1 / 2}(T, I) / F$. It is also possible to determine $\Delta S_{O / R}(T, 0)$, plotting $E_{O / R}(T, 0)$ versus $T$. For each temperature we obtained with the $S$. I. T. a value of $\Delta \epsilon^{\prime}(\mathrm{T})$. The variation of these experimental values with temperature is linear from 5 up to $55^{\circ} \mathrm{C}$. All these results in carbonate medium are in Table 2.

Studying the influence of both ionic strength and temperature allows us to correlate all measurements made in different experimental conditions and to predict by extrapolation the redox potentials in groundwaters. 
Table 1

Results in acidic medium $\left(\mathrm{HClO}_{4} 1 \mathrm{M} ; \mathrm{I}=1.05 \mathrm{~mol} / \mathrm{kg}\right)$

Table 1a: Potentials measured against $\mathrm{Ag} / \mathrm{AgCl} \mathrm{E}_{\mathrm{Ref}}\left(25^{\circ} \mathrm{C}\right.$,

$1.05)=327.8 \mathrm{mV}$ (calculated using the S.I.T)

\begin{tabular}{rcc}
$\begin{array}{c}\mathrm{T}, \\
{ }^{\circ} \mathrm{C}\end{array}$ & $\begin{array}{c}\mathrm{E}\left(\mathrm{UO}_{2}^{2+} / \mathrm{UO}_{2}^{+}\right), \\
\mathrm{mV}\end{array}$ & $\begin{array}{c}\mathrm{E}\left(\mathrm{U}^{4+} / \mathrm{U}^{3+}\right), \\
\mathrm{mV}\end{array}$ \\
\hline 5 & -268 & -990 \\
15 & -269 & -974 \\
25 & -268 & -960 \\
35 & -268 & -944 \\
45 & -267 & -928 \\
55 & -266 & -912 \\
\hline
\end{tabular}

Table 1b:

\begin{tabular}{lccc}
\hline & $\mathrm{UO}_{2}^{2+} / \mathrm{UO}_{2}^{+}$ & $\mathrm{U}^{4+} / \mathrm{U}^{3+}$ \\
\hline $\mathrm{E}_{\mathrm{O} / \mathrm{R}}\left(25^{\circ} \mathrm{C}, 1.05\right)(\mathrm{mV})$ & $60 \pm 4$ & $-630 \pm 4$ \\
$\Delta \mathrm{S}_{1 / 2}(\mathrm{~T}, 1.05) / \mathrm{F}\left(\mathrm{mV} /{ }^{\circ} \mathrm{C}\right)$ & $0.0 \pm 0.3$ & $1.5 \pm 0.3$ \\
\hline
\end{tabular}

$\mathrm{E}_{\mathrm{O} / \mathrm{R}}\left(25^{\circ} \mathrm{C}, 1.05\right)$ are calculated from table 1a values and $\mathrm{E}_{\mathrm{Ref}}\left(25^{\circ} \mathrm{C}, 1.05\right)$.

$\Delta \mathrm{S}_{1 / 2}(\mathrm{~T}, 1.05) / \mathrm{F}=\frac{\Delta \mathrm{E}(\mathrm{T}, 1.05)}{\Delta \mathrm{T}}$ where $\mathrm{E}(\mathrm{T}, 1.05)$ and

$\mathrm{T}$ are Table 1a values.

\section{Discussion}

The shift of redox potentials observed between carbonate and acidic media are due to

$$
\mathrm{UO}_{2}^{2+}+3 \mathrm{CO}_{3}^{2-} \rightleftharpoons \mathrm{UO}_{2}\left(\mathrm{CO}_{3}\right)_{3}^{4-}
$$

and

$$
\mathrm{UO}_{2}^{+}+3 \mathrm{CO}_{3}^{2-} \rightleftharpoons \mathrm{UO}_{2}\left(\mathrm{CO}_{3}\right)_{3}^{5-}
$$

whose equilibrium costants are $\beta_{3} U(V I)$ and $\beta_{3} U(V)$. We calculated the expression $\log \frac{\beta_{3} U(V I)}{\beta_{3} U(V)}$ using the equation: 
Table 2

Results in carbonate medium $\left[0.2 \mathrm{M} \mathrm{Na}_{2} \mathrm{CO}_{3}, \times \mathrm{M} \mathrm{NaClO}_{4}\right]$

Table 2a: Potentials measured against $\mathrm{Ag} / \mathrm{AgCl} \mathrm{E}_{1 / 2}(\mathrm{~T}, \mathrm{I})(\mathrm{mV})$

\begin{tabular}{ccccccc}
\hline I, mol/kg & $5^{\circ}{ }^{\circ} \mathrm{C}$ & $15{ }^{\circ} \mathrm{C}$ & $25{ }^{\circ} \mathrm{C}$ & $35{ }^{\circ} \mathrm{C}$ & $45{ }^{\circ} \mathrm{C}$ & $55^{\circ} \mathrm{C}$ \\
\hline 3.66 & -799 & -820 & -840 & -861 & -882 & -902 \\
2.15 & -854 & -868 & -882 & -895 & -909 & -921 \\
1.24 & -919 & -932 & -944 & -956 & -966 & -980 \\
0.6 & -971 & -981 & -992 & -1003 & -1015 & -1027 \\
\hline
\end{tabular}

Table 2b: Results of the extrapolation to $\mathrm{I}=0$

\begin{tabular}{ccccccc}
\hline $\begin{array}{c}\mathrm{T}, \\
{ }^{\circ} \mathrm{C}\end{array}$ & $\begin{array}{c}\mathrm{A}, \\
\mathrm{mV}\end{array}$ & $\begin{array}{c}\mathrm{E}_{1 / 2}(\mathrm{~T}, 0), \\
\mathrm{mV}\end{array}$ & $\begin{array}{c}(\Delta \epsilon+\epsilon)(\mathrm{T}), \\
\mathrm{kg} / \mathrm{mol}\end{array}$ & $\begin{array}{c}\mathrm{E}_{\mathrm{Agg} / \mathrm{AgCl}} \\
(\mathrm{T}, 0), \mathrm{mV}\end{array}$ & $\begin{array}{c}\mathrm{E}_{\mathrm{Ref}}(\mathrm{T}, 0) \\
\mathrm{mV}\end{array}$ & $\begin{array}{c}\mathrm{E}_{\mathbf{O} / \mathbf{R}}(\mathrm{T}, 0), \\
\mathrm{mV}\end{array}$ \\
\hline 05 & 55.19 & -1073 & 1.12 & 232.1 & 325.9 & -747.1 \\
15 & 57.17 & -1090 & 1.05 & 228.9 & 326.0 & -764.0 \\
25 & 59.16 & -1102 & 0.95 & 222.6 & 323.1 & -778.9 \\
35 & 61.15 & -1119 & 0.90 & 215.2 & 319.1 & -799.9 \\
45 & 63.13 & -1131 & 0.82 & 207.6 & 314.9 & -816.1 \\
55 & 65.12 & -1149 & 0.79 & 198.4 & 309.0 & -840.0 \\
\hline
\end{tabular}

$A=\frac{R T \ln 10}{F}$.

$\mathrm{E}_{1 / 2}(\mathrm{~T}, 0)$ and $(\Delta \epsilon+\epsilon)(\mathrm{T})$ are obtained from linear regression (using the S.I.T.) on Table 2a data.

$\mathrm{E}_{\mathrm{Ag} / \mathrm{AgCl}}(\mathrm{T}, 0)$ are published.'

$E_{\text {Ref }}(T, 0)=E_{A g / A g C l}(T, 0)-A \log (0.02)$.

$E_{o / R}(T, 0)=E_{1 / 2}(T, 0)+E_{R e f}(T, 0)$.

Table 2c: Results of temperature study

\begin{tabular}{lccccc}
\hline $\mathrm{I}, \mathrm{mol} / \mathrm{kg}$ & 3.66 & 2.15 & 1.24 & 0.6 & 0 \\
$\Delta \mathrm{S} / \mathrm{F}, \mathrm{mV}$ & $-2 \pm 0.3$ & $-1.3 \pm 0.3$ & $-1.2 \pm 0.3$ & $-1.1 \pm 0.3$ & $-1.8 \pm 0.5$ \\
\hline
\end{tabular}

For $I \neq 0, \Delta S / F$ means $\Delta S_{1 / 2}(T, I)[E q(11)]$.

For $\mathrm{I}=0, \Delta \mathrm{S} / \mathrm{F}$ means $\Delta \mathrm{S}_{\mathrm{o} / \mathrm{R}}(\mathrm{T}, 0)[\mathrm{Eq}(12)]$.

\begin{tabular}{lcccccc}
\hline $\mathrm{T},{ }^{\circ} \mathrm{C}$ & 5 & 15 & 25 & 35 & 45 & 55 \\
$\Delta \epsilon^{\prime}, \mathrm{kg} / \mathrm{mol}$ & 1.12 & 1.05 & 0.95 & 0.9 & 0.82 & 0.79 \\
\hline
\end{tabular}

$\Delta \epsilon^{\prime}(\mathrm{T})=1.14+0.007 \mathrm{~T}$.

$\epsilon_{\mathrm{Cl}^{-}}\left(25^{\circ} \mathrm{C}\right)=0.03[6]$, so $\Delta \epsilon\left(25^{\circ} \mathrm{C}\right)=0.92 \mathrm{~kg} / \mathrm{mol}$. 


\section{H. CAPDEVILA, P. VITORGE: TEMPERATURE AND IONIC STRENGTH INFLUENCE}

Table 3

Table 3a: Selected literature data in carbonate medium (redox potentials and complexation constants)

\begin{tabular}{lcccc}
\hline & $\mathrm{U}$ & $\mathrm{Np}$ & $\mathrm{Pu}$ & $\mathrm{Am}$ \\
\hline$\beta_{3} \mathrm{M}(\mathrm{V})$ & & $8.53(1 \mathrm{M})(\mathrm{a})$ & & \\
$\beta_{3} \mathrm{M}(\mathrm{VI})$ & $22.6(3 \mathrm{M})(\mathrm{b})$ & & $18.2(3 \mathrm{M})(\mathrm{c})$ & \\
& $21.3(0 \mathrm{M})(\mathrm{b})$ & & & \\
$\mathrm{E}(\mathrm{VI} / \mathrm{V})$ & $-523.6(3 \mathrm{M})(\mathrm{d})$ & $450(1 \mathrm{M})(\mathrm{e})$ & $350(1 \mathrm{M})(\mathrm{a})$ & $964(2 \mathrm{M})(\mathrm{f})$ \\
& $779(0 \mathrm{M})(\mathrm{g})$ & & & \\
\hline
\end{tabular}

(a): [8-9]; (b): [4]; (c): [3]; (d): [10]; (e): [8,11, 12] (f): [3]; (g): this work. $(\mathrm{xM})$ : ionic strength (mol/l).

From these data (Table $3 \mathrm{a}$ ) and the following interaction coefficients:

$\epsilon\left(\mathrm{MO}_{2}\left(\mathrm{CO}_{3}\right)_{3}^{4-}, \mathrm{Na}{ }^{+}\right)=0.09 \mathrm{~kg} / \mathrm{mol}[6]$

$\epsilon\left(\mathrm{MO}_{2}\left(\mathrm{CO}_{3}\right)_{3}^{5-}, \mathrm{Na}^{+}\right)=-0.62 \mathrm{~kg} / \mathrm{mol}$ for $\mathrm{Np}[8]$ and $-0.83 \mathrm{~kg} / \mathrm{mol}$ for $\mathrm{U}$ [this work];

$E\left(\mathrm{CO}_{3}^{2-}, \mathrm{Na}^{+}\right)=-0.05 \mathrm{~kg} / \mathrm{mol}[6]$;

$\epsilon\left(\mathrm{MO}_{2}^{2+}, \mathrm{Na}^{+}\right)=0.46 \mathrm{~kg} / \mathrm{mol}[6]$

we calculated the thermodynamic constants at $\mathrm{I}=0 \mathrm{M}$ (Table $3 \mathrm{~b}$ ).

Table 3b:

\begin{tabular}{lrrrr} 
& $\mathrm{U}$ & \multicolumn{1}{c}{$\mathrm{Np}$} & \multicolumn{1}{c}{$\mathrm{Pu}$} & \multicolumn{1}{c}{$\mathrm{Am}$} \\
\hline$\Delta \mathrm{E} / 59.16$ & 14.7 & 14.6 & 12.8 & $(11.6)$ \\
$\log \beta_{3} \mathrm{M}(\mathrm{V})$ & 6.6 & 5.4 & 4.6 & $(3.6)$ \\
$\log \beta_{3} \mathrm{M}(\mathrm{VI})$ & 21.3 & 19.0 & 17.4 & $(15.2)$ \\
\hline
\end{tabular}

$\Delta \mathrm{E}=\mathrm{E}\left(\mathrm{MO}_{2}^{2+} / \mathrm{MO}_{2}^{+}\right)-\mathrm{E}\left(\mathrm{MO}_{2}\left(\mathrm{CO}_{3}\right)_{3}^{4-} / \mathrm{MO}_{2}\left(\mathrm{CO}_{3}\right)_{3}^{5-}\right)(\mathrm{mV})$,

$\mathrm{E}\left(\mathrm{MO}_{2}^{2+} / \mathrm{MO}_{2}^{+}\right)[8]$

$\mathrm{A}=59.16 \mathrm{mV}\left(25^{\circ} \mathrm{C}\right)$.

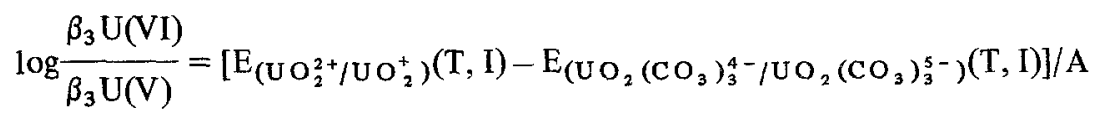

We deduced the constant $\beta_{3} U(V)$ from published $\beta_{3} U(V I):{ }^{4}$ from the potentials measured, we obtained $\beta_{3} U(V)$ values at different $I$, and from the standard potentials

$$
\log \beta_{3} \mathrm{U}(\mathrm{V})=6.6 \pm 0.3 \quad \text { (at } \mathrm{I}=0 \text { ). }
$$

We have then compared the published results in carbonate medium for the actinides $\mathrm{U}, \mathrm{Np}, \mathrm{Pu}, \mathrm{Am}$ (Table 3). To correlate the values and to determine the constants at 
$\mathrm{I}=0$ we had to extrapolate using the S. I. T. (Table $3 b) . \beta_{3} \mathrm{U}(\mathrm{V})$ values at $\mathrm{I}=1 \mathrm{M}^{8}, 9$ and $\mathrm{E}\left(\mathrm{UO}_{2}\left(\mathrm{CO}_{3}\right)_{3}^{4-} / \mathrm{UO}_{2}\left(\mathrm{CO}_{3}\right)_{3}^{5-}\right)$ at $\mathrm{I}=3 \mathrm{M}[10$ and this work] determined using two different experimental methods are in agreement. For all the actinides the carbonate complex of the oxidant is more stable than that of the reductant. Both $\beta_{3} \mathrm{U}(\mathrm{VI})$ and $\beta_{3} \mathrm{U}(\mathrm{V})$ constants decrease when atomic number increases. These values are only known up to $\mathrm{Pu}$; we extrapolated $\beta_{3} \mathrm{U}(\mathrm{VI})$ and $\beta_{3} \mathrm{U}(\mathrm{V})$ variations versus $\mathrm{Z}$, to Am (Table 3b). Using Eqs (15) and [3], we calculated the $\mathrm{AmO}_{2}^{2+} / \mathrm{AmO}_{2}^{+}$redox potential (at $I=0$ ), which is experimentally difficult to measure

$$
\mathrm{E}\left(\mathrm{AmO}_{2}^{2+} / \mathrm{AmO}_{2}^{+}\right)\left(25^{\circ} \mathrm{C}, 0\right)=1443 \mathrm{mV}
$$

This work allows us to support the S. I. T. and measure $\Delta \epsilon^{\prime}(\mathrm{T})$ between 5 and $55{ }^{\circ} \mathrm{C}$. We have to point out that the S. I. T. fit correctly our uranium data in carbonate medium only up to $\mathrm{I}=2 \mathrm{M}$. This results has already been noticed in neptunium study; ${ }^{8}$ this might be due to the formation of an ion pair such as $\left(\mathrm{UO}_{2}\left(\mathrm{CO}_{3}\right)_{3}^{5-}, \mathrm{Na}^{+}\right)$.

Temperature influence on interaction coefficients is small and linear (Table 2c).

In acidic medium for $\mathrm{VI} / \mathrm{V}$ or $\mathrm{IV} / \mathrm{III}$ system, our $\Delta \mathrm{S}$ values are in agreement with published ones (Table 4). The VI/V systems (for $\mathrm{U}, \mathrm{Np}$ or $\mathrm{Pu}$ ) are less sensitive to temperature than IV/III systems. In carbonate medium (extrapolated values at $I=0$ ):

$$
\frac{\Delta \mathrm{S}_{\mathrm{O} / \mathrm{R}}}{\mathrm{F}}=-1.8 \pm 0.5 \mathrm{mV} /{ }^{\circ} \mathrm{C}
$$

Table 4

Entropy values. Comparison between our data and published ones

\begin{tabular}{|c|c|c|c|c|c|c|c|}
\hline & \multicolumn{3}{|c|}{ VI/V Systems } & \multicolumn{3}{|c|}{ IV/III Systems } & \multirow{2}{*}{ Source } \\
\hline & $\mathrm{U}$ & $\mathrm{Np}$ & $\mathrm{Pu}$ & $\mathrm{U}$ & $\mathrm{Np}$ & $\mathrm{Pu}$ & \\
\hline$\Delta \mathrm{S} / \mathrm{F} \mathrm{mV} /{ }^{\circ} \mathrm{C}$ & $0.0 \pm 0.3$ & & $1.2 \pm 0.4$ & $1.5 \pm 0.3$ & & & $\begin{array}{l}\text { (a) } \\
\text { (b) }\end{array}$ \\
\hline & & 0.215 & 0.655 & & 1.867 & $\begin{array}{c}2.2 \pm 0.4 \\
1.526\end{array}$ & $\begin{array}{l}\text { (c) } \\
\text { (d) }\end{array}$ \\
\hline
\end{tabular}
Acidic medium $\left(\mathrm{HClO}_{4}=1 \mathrm{M}\right)$

(a): This work; (b): Ref. 13; (c): Ref. 14; (d): Ref. 15. 
H. CAPDEVILA, P. VITORGE: TEMPERATURE AND IONIC STRENGTH INFLUENCE

\section{References}

1. Ch. RIGLET, P. VITORGE, I. GRENTHE, Inorg. Chim. Acta, 133 (1987) 323.

2. Ch. RIGLET, P. ROBOUCH, P. VITORGE, Radiochim. Acta, 46 (1989) 85.

3. P. ROBOUCH, Report CEA $5473,1988$.

4. I. GRENTHE, D. FER RI, F. SALVATORE, G. RICCIO, J. Chem. Soc. Dalton Trans., 2439 (1984).

5. I. GRENTHE, P. ROBOUCH, P. VITORGE, J. Less Common Met. 127 (1986) 225.

6. I. GRENTHE, H. WANNER, Chemical Thermodynamics of Uranium, OCDE NEA TDB, to be published.

7. J. BARD, R. PARSONS, J. JORDAN, Standard potentials in Aqueous Solution, M. Dekker, Inc., New York, NY10016, 1986, p. 304.

8. Ch. RIGLET, Chimie du Neptunium et autres Actinides en Milieu Carbonate, Thesis, March 17, 1989, Paris VI University, France.

9. L. MAYA, Inorg. Chem., 22 (1983) 2093.

10. D. FERRI I. GRENTHE, F. SALVATORE, Inorg. Chem. 22 (1983) 3162.

11. G. A. SIMAKIN, Elekt rokhimiya, 11 (1975) 1026.

12. T. W. NEWTON, J. C. SULLIVAN, Handbook of the Physics and Chemistry of the Actinides, Vol. 3, Ch. 10. A. J. FREEMAN, C. KELLER (Eds), 1985.

13. S. W. RABIDEAU, J. Am. Chem. Soc., 78 (1956) 2705.

14. R. E. CONNICK, W. H. M. VEY, J. Am. Chem. Soc., 73 (1951) 1798.

15. P. BLANC, Report CEA 5406, 1987. 